\title{
Effect of a Short Nutritional Training Program on Nutrition Literacy and Food Habits in Adolescents
}

\author{
Indrani Kalkan (D), Fatma Feyzan Aydin (D) \\ Istanbul Aydin University, Nutrition and Dietetics Department, Istanbul, Turkey.
}

Correspondence Author: Indrani Kalkan

E-mail: indranikalkan@aydin.edu.tr

Received: 26.11.2019 Accepted: 20.03.2020

\begin{abstract}
Objective: Balanced nutrition is of special importance in adolescence however, eating behaviors may be negatively influenced during this stage due to several factors. The objective of this research was to investigate the effect of a nutrition training program on nutrition literacy level and food habits of a group of adolescents.

Methods: Adolescent Nutritional Literacy Scale (ANLS) and Adolescent Food Habits Checklist (AFHC) was used to determine the nutrition literacy level and food habits of 200 highschool students in Istanbul between September 2018 and April 2019. Effect of a face to face training, for 8 hrs over 4 weeks on nutrition related topics, were investigated on nutrition literacy level and food habits of the students.

Results: Mean age of the students was $15 \pm 0,66$ years and $57 \%$ comprised of females. ANLS and AFHC scores in general, were higher in females, however the difference was statistically significant $(p<0,05)$ only in pre-test scores. The average adolescent nutrition literacy (ANLS) score in males were 3,31 out of 5,0 and remained unchanged after training. In females however, it significantly decreased from 3,56 to 3,44 ( $p<0,05$ ). Out of 19, AFHC scores decreased significantly from 9,80 to 8,94 in males and 10,03 to 9,34 in females $(p<0,05)$ following training.

Conclusion: A short nutritional training was not sufficiently effective in reflecting the positive change in nutrition literacy level and food habits among adolescents. Possible reasons should be investigated in depth and more comprehensive and longer training should be provided to increase nutritional awareness.
\end{abstract}

Keywords: Adolescent, nutrition, nutrition literacy, food habits.

\section{INTRODUCTION}

Adolescence is described as a transitory period between childhood and adulthood during which growth and development are the fastest in an individual leading to an increasing need for energy, protein, vitamins and minerals in the diet (1). Studies conducted with adolescents indicate that although individuals are aware of the importance of adequate and balanced nutrition in health and prevention of diseases; however, they fail to apply the knowledge in their everyday life (2). Peer influences, unhealthy eating habits as skipping of meals, increased consumption of fast food and sugar added beverages, snacking as well as lack of physical activity lead to obesity and other health risk factors in this age group (3). Psychosomatic disorders as stress, depression, social anxiety disorders, faulty body image perception, self esteem etc. also lead to eating disorders and inadequate nourishment during this age $(4,5)$.

In this context, there is a need for nutritional interventional programs to raise the awareness of youth enabling them to increase nutritional knowledge level and adopt healthy eating and lifestyle. The term nutrition literacy has gained popularity over the last decade and is defined as the degree to which people can process, and understand basic nutrition information (2).

Nutrition literacy was found to have a positive effect on food habits in a group of young Turkish adults and based on the findings the author suggested administration of nutritional training programs in order to raise nutrition awareness in adolescents (3). However, the content and length of the training program that would be adequate to bring about the desired effect is an issue that must be researched thoroughly.

The objective of this research was to study the nutrition literacy level and food habits of a group of high school students, as well as to investigate the effect of a short nutrition training program on both. 


\section{METHODS}

\subsection{Participants and Setting}

The prospective cross sectional study was conducted on all students $(n=200)$ who had voluntarily wished to participate in the study and were studying in grade 10 and 11 of a high school (Fahrettin Kerim Gökay Anatolian High School) in Istanbul randomly chosen in a neighbourhood having families of mixed economic and social status. The study was conducted between September 2018 and April 2019.

\subsection{Instruments}

A questionnaire with 18 general questions regarding demographic characteristics was directed to the participants followed by the validated Adolescent Nutrition Literacy Scale (ANLS) tool developed by Bari, 2012 (6) and validated in Turkey by Türkmen et al, 2017 (7).

The validated ANLS scale comprised of 22 questions listed under three sub-groups namely Functional Nutrition Literacy (FNL), Interactive Nutrition Literacy (INL) and Critical Nutrition Literacy (CNL) (2). FNL indicated the individual's knowledge and follow up of literature in the field of nutrition. INL indicated the individual's application of nutrition knowledge in practical life and CNL reflected his/her tendency to participate and take an active role in nutrition related topics. Every item was scored between 1-5 on a "5 point likert type scale" ( 1 = strongly disagree, 2 = disagree, 3 $=$ neutral, $4=$ agree, $5=$ strongly agree) $(6,7)$. A mean score out of 3.0 or more out 5.0 could be considered to be above average nutrition literacy level among the participants (7). Finally, Adolescent Food Habits Checklist (AFHC) developed by Johnson et al. 2002 (8) and validated in the Turkish language by Arikan et al. 2012, comprising of 19 items was aimed at measuring healthy eating behavior of adolescents was administered on the participants. A positive / negative (Yes/No) response format was selected to make the checklist easier to complete. Participants were granted one point for each 'healthy' response. The maximum score to be attained by the Turkish version of AFHC instrument was determined to be 19. Attaining a high score demonstrated healthy eating habits on the part of the individual (9). The questionnaires were filled by the students in the lecture hall in presence of the research team. The tools were applied twice, one prior to the training and afterwards, to study the effect of the training program on ANLS and AFHC scores.

\subsection{Nutritional Training Program}

After the three questionnaires were conducted, a short nutritional face to face training comprising of 8 lecture hours ( 2 hours each week for 4 weeks) was provided to the students. The lectures were given by the research team members, supported by visuals, videos, printed materials and interactive discussion. The nutritional training material comprised of topics as nutritional terminology, concept of nutrition literacy, healthy eating, diet related chronic diseases, food safety, healthy food selection, reading of food labels etc. The training material also included subjects as preparation of an adequate and balanced menu by choosing the right foods, nutrients, and food sources, normal body weight, body mass index etc. Some of the measurement techniques as height and weight as well as calculation of body mass index were applied in class. After 3 months, the questionnaires were repeated on the same participants to evaluate the effects of the training.

\subsection{Ethical Aspects of the Study}

Permission was sought from Istanbul Provincial Directorate for National Education and ethical approval was taken from Istanbul Aydin University Ethical Committee dated February 2018 prior to the study. All participants and families were informed about the research work and their consent was taken.

\subsection{Statistical Analyses}

Descriptive statistics (frequency, mean, standard deviation) were used to analyse the data. Differences between two independent groups (female and male) were analysed by Independent Sample T Test. Differences between two dependent numerical variables (for example, interactive nutrition literacy scores before and after education) were analyzed using the Dependent Sample $T$ Test. The relationships between two independent numerical variables (ANLS and AFHC scores) were evaluated by Pearson Correlation Coefficient. Statistical significance was accepted as $p<0.05$. Statistical analyses were carried out using the SPSS version 23.0 Statistical Package Program.

\section{RESULTS}

Number of students included in the study was 200 of which $57 \%$ were females. The demographic characteristics of the participants have been summarized in Table 1.

On enquiring about frequency of skipping meals among participants, 60,5\% consumed three major meals, 29,5 $\%$ consumed 2 major meals in a day. Regarding snacking habits, $50,5 \%$ of the students skipped snacks, $34 \%$ stated that they snacked twice in a day, 15,5 \% snacked more than twice in a day. Among the preferred beverages during snacks. The most popular was tea $(50,5 \%)$ followed by butter milk $(43,5 \%)$ and milk (39\%). Most preferred snack item was chocolate bars $(65 \%)$ followed by cookies $(57,5 \%)$ and salty crackers (49\%).

The amount of water/beverage consumption in day by the students has been summarized in Table 2 . As per results, only $42 \%$ consumed $2 \mathrm{~L}$ or more of water in a day whereas, $47,5 \%$ consumed up to $200 \mathrm{ml}$ and $9,5 \%$ consumed up to $500 \mathrm{ml}$ of sugar added beverages in a day. 
Table 1. Demographic Characteristics of the participants $(n=200)$

\begin{tabular}{|c|c|c|}
\hline Gender & Frequency & Percent (\%) \\
\hline Female & 114 & 57,0 \\
\hline Male & 86 & 43,0 \\
\hline \multicolumn{3}{|l|}{ Age } \\
\hline 15 Years & 107 & 53,5 \\
\hline 16 Years & 74 & 37,0 \\
\hline 17 Years & 18 & 9,0 \\
\hline \multicolumn{3}{|l|}{ Body Weight } \\
\hline$\leq 50 \mathrm{~kg}$ & 35 & 17,5 \\
\hline $51-60$ kg & 82 & 41,0 \\
\hline$\geq 61 \mathrm{~kg}$ & 83 & 41,5 \\
\hline \multicolumn{3}{|l|}{ Height } \\
\hline$\leq 165 \mathrm{~cm}$ & 77 & 38,5 \\
\hline $166-175 \mathrm{~cm}$ & 75 & 37,5 \\
\hline$\geq 176 \mathrm{~cm}$ & 48 & 24,0 \\
\hline \multicolumn{3}{|c|}{ Monthly Allowance for Food } \\
\hline$\leq 100 \mathrm{TL}$ & 70 & 35,0 \\
\hline $101-200 \mathrm{TL}$ & 74 & 37,0 \\
\hline$\geq 201 \mathrm{TL}$ & 56 & 28,0 \\
\hline \multicolumn{3}{|c|}{ Performing Sports on a Regular Basis } \\
\hline Yes & 88 & 44,0 \\
\hline No & 112 & 56,0 \\
\hline
\end{tabular}

Table 2. Consumption of Water/Beverages on a Daily Basis $(n=200)$

\begin{tabular}{ccc}
\hline Daily Consumption of Water & Frequency & Percent (\%) \\
\hline $400 \mathrm{ml}$ or less & 5 & 2,5 \\
$401-1000 \mathrm{ml}$ & 57 & 28,5 \\
$1001-1500 \mathrm{ml}$ & 35 & 17,5 \\
$1501-2000 \mathrm{ml}$ & 19 & 9,5 \\
$2000 \mathrm{ml}$ or more & 84 & 42,0 \\
Daily Consumption of Tea/Coffee & & 13,0 \\
Does not Consume & 26 & 58,0 \\
$0-200 \mathrm{ml}$ & 116 & 24,5 \\
$201-500 \mathrm{ml}$ & 49 & 4,5 \\
$501-1000 \mathrm{ml}$ & 9 & \\
\hline Daily Consumption of Sugar Added Beverages & & 38,5 \\
Does not Consume & 77 & 47,5 \\
\hline $201-500 \mathrm{ml}$ & 95 & 9,5 \\
\hline
\end{tabular}

FNL mean scores of students increased from 3,53 to 3,59 after training. However, INL mean score decreased from 3,24 to 3,17 . However, these changes were not statistically significant $(p>0,05)$. On the other hand, decrease in CNL score from 3,61 to 3,53 after training was found to be statistically significant $(p<0,05)$. Also, general ANLS means score decreased from 3,45 to 3,39 after training. Similarly, AFHC mean score also decreased from 9,93 pre-training to 9,17 post-training. Decrease in these values were also found to be statistically significant $(p<0,05)$. Effects of training on Mean ANLS Subgroups, and AFHC scores have been illustrated in Figure 1. 
Figure 1. Effects of Training on Mean ANLS Subgroup and AFHC Scores

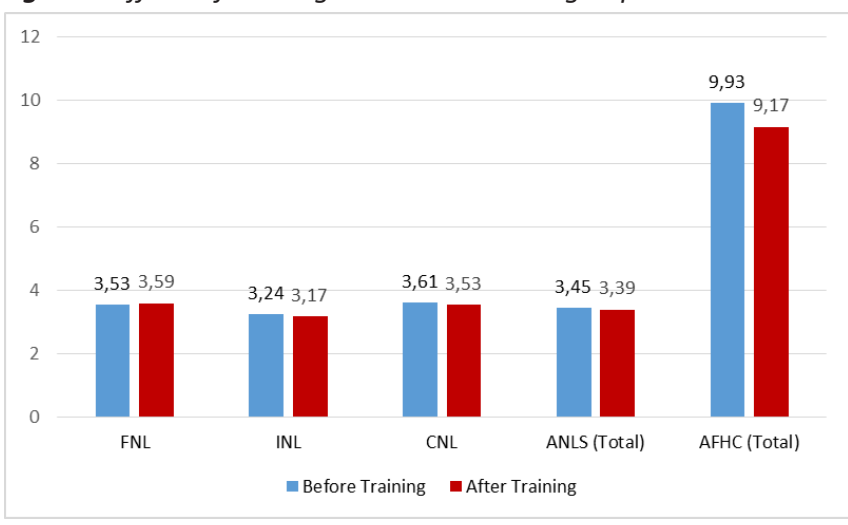

FNL: Functional Nutrition Literacy, INL: Interactive Nutrition Literacy, CNL: Critical Nutrition Literacy, ANLS: Adolescent Nutrition Literacy Scale, AFHC: Adolescent Food Habits Checklist

Effect of training was analysed for all items based on gender results of which have been summarized in Table 3. In general, ANLS scores and subgroup scores were higher in females as compared to males. However, ANLS pre-training and CNL pre and post training scores were found to be statistically higher in females (Table: 3 ).

Contrary to what was expected, effect of training exhibited negative results. Apart from FNL, other subgroups of ANLS tool and AFHC scores fell after the training and this decrease was found to be statistically significant as shown in Table 3.

Table 3. Effects of Training on ANLS Subgroups and AFHC Scores Based on Gender( $n=200)$

\begin{tabular}{|c|c|c|c|c|}
\hline & Female $(n=114)$ & Male $(n=86)$ & & \\
\hline & Mean S.D. & Mean S.D. & $\mathrm{t}$ & $\mathbf{p}^{\mathrm{a}}$ \\
\hline FNL (BT) & $3,570,516$ & $3,470,735$ & 1,047 & 0,297 \\
\hline \multirow[t]{2}{*}{ FNL (AT) } & $3,600,643$ & $3,570,829$ & 0,301 & 0,764 \\
\hline & $t=-0,585 p^{b}=0,559$ & $t=-1,017 p^{b}=0,312$ & & \\
\hline INL (BT) & $3,330,651$ & $3,130,863$ & 1,746 & 0,083 \\
\hline \multirow[t]{2}{*}{ INL (AT) } & $3,180,666$ & $3,160,844$ & 0,247 & 0,805 \\
\hline & $t=2,300 p^{b}=0,023^{*}$ & $t=-0,277 p^{b}=0,782$ & & \\
\hline CNL (BT) & $3,800,694$ & $3,361,095$ & 3,250 & $0,001^{*}$ \\
\hline \multirow[t]{2}{*}{ CNL (AT) } & $3,710,533$ & $3,300,748$ & 4,380 & $0,000 *$ \\
\hline & $t=2,677 p^{b}=0,009 *$ & $t=1,117 p^{b}=0,267$ & & \\
\hline ANLS (BT) & $3,560,421$ & $3,310,552$ & 3,692 & $0,000 *$ \\
\hline \multirow[t]{2}{*}{ ANLS (AT) } & $3,440,4999$ & $3,310,554$ & 1,767 & 0,079 \\
\hline & $t=3,085 p^{b}=0,003^{*}$ & $t=-0,050 p^{b}=0,960$ & & \\
\hline AFHC (BT) & $10,033,571$ & $9,803,467$ & 0,445 & 0,657 \\
\hline AFHC (AT) & $9,343,788$ & $8,944,533$ & 0,663 & 0,508 \\
\hline & $t=2,365 p^{b}=0,020^{*}$ & $t=2,127 p^{b}=0,036^{*}$ & & \\
\hline
\end{tabular}

$p^{a}=$ Independent variable (between gender)

$p^{b}=$ Dependent variable (within gender)

$p<0,05$ (statistically significant) BT= Before Training AT=After Training

FNL: Functional Nutrition Literacy INL: Interactive Nutrition Literacy CNL: Critical Nutrition Literacy BT: Before Training AT: After Trainig
Pearson Correlation test was conducted to study the correlation between ANLS (including sub-groups) and AFHC tool. As per findings, there is a significant positive correlation between ANLS (including sub-groups) pre-test and post-test scores with AFHC pre-test and post-test scores $(p<0,05)$. The degree of correlation was weak in some cases and moderate in others. The results have been summarized in Table 4.

Table 4. Correlation between ANLS and AFHC Tools $(n=200)$

\begin{tabular}{|c|c|c|c|}
\hline ANLS & & AFHC & \\
\hline Sub-Groups & & Pre-Test & Post-Test \\
\hline \multirow{2}{*}{ FNL Pre-Test } & $r$ &, $234^{* *}$ &, $261^{* *}$ \\
\hline & $p$ & 0,001 & 0,000 \\
\hline \multirow{2}{*}{ INL Pre-Test } & $r$ &, $374^{* *}$ &, $299^{* *}$ \\
\hline & $p$ & 0,000 & 0,000 \\
\hline \multirow{2}{*}{ CNL Pre-Test } & $r$ &, $347^{* *}$ & $244^{* *}$ \\
\hline & $p$ & 0,000 & 0,001 \\
\hline \multirow{2}{*}{ ANLS Pre-Test } & $r$ & $437^{* *}$ & $340^{* *}$ \\
\hline & $p$ & 0,000 & 0,000 \\
\hline \multirow{2}{*}{ FNL Post-Test } & $r$ &, $248^{* *}$ &, $321^{* *}$ \\
\hline & $p$ & 0,000 & 0,000 \\
\hline \multirow{2}{*}{ INL Post-Test } & $r$ &, $317^{* *}$ & $416^{* *}$ \\
\hline & $p$ & 0,000 & 0,000 \\
\hline \multirow{2}{*}{ CNL Post-Test } & $r$ &, $345^{* *}$ & $205^{* *}$ \\
\hline & $p$ & 0,000 & 0,004 \\
\hline \multirow{2}{*}{ ANLS Post-Test } & $r$ & $446^{* *}$ &, $507^{* *}$ \\
\hline & $\mathrm{p}$ & 0,000 & 0,000 \\
\hline
\end{tabular}

$r:$ Pearson Korelasyon $*: p<0,05 * *: p<0,01$

\begin{tabular}{ccc}
\hline $\boldsymbol{r}$ & Degree of Correlation & Direction of Correlation \\
\hline 0,00 & No Correation & $r=-$ negative \\
$0,01-0,29$ & Weak Correlation & $r=+$ positive \\
$0,30-0,69$ & Medium Correlation & \\
$0,70-0,99$ & Strong Correlation & \\
1,00 & Perfect Correlation & \\
\hline
\end{tabular}

FNL: Functional Nutrition Literacy, INL: Interactive Nutrition Literacy, CNL: Critical Nutrition Literacy

\section{DISCUSSION}

This study evaluated the effect of a short nutritional training program on Adolescent Nutritional Literacy (ANLS) and Food Habits (AFHC) of a group of high school students.

In this study, $56 \%$ of the students stated that they could not spare time for regular sports or physical activity on a daily basis. Aksoydan et al. in their study with adolescents reported that only $15,7 \%$ of adolescents performed sports for 4 hours or more in a week, and the main reason suggested was the long hours spent by them in front of electronic devices such as smart phones and computers (10). According to the WHO 
report, $77,1 \%$ of young Turkish men and $86,9 \%$ of young women maintained an inactive lifestyle (11). Regular physical activity has been suggested to increase bone density, lean tissue mass and rate of basal metabolism whereas decrease body fat and prevent the occurrence of chronic diseases such as obesity, hypertension, diabetes, coronary heart disease (12).

In this study, $0,5 \%$ of adolescents stated that they consumed three meals whereas $29,5 \%$ consumed two meals during the day. Meal skipping behavior is common during adolescence. In a study conducted on 411 university students in which nutritional habits, physical activity levels and body mass indexes of adolescents were evaluated, $59,5 \%$ of students consumed three meals a day, but $20,9 \%$ consumed two meals. It has been suggested that as the number of meals decreases, the availability of nitrogen in the body decreases. There is an increase in glucose absorption, glycogen synthesis and fat storage leading to metabolic disorders. On the other hand, increasing meal frequency in a day without increasing the amount of food consumption resulted in a significant decrease in blood LDL cholesterol (13).

The most popular beverage among students was found to be tea followed by the buttermilk. Consumed by $50,5 \%$ and most popular snack item was chocolate bars followed by cookies and salty crackers. Snacking item preference by students in this study was very similar to the study performed by Kalkan et al in Konya on 643 high school students (14). Students' desire to consume such snack items frequently is due to their easy accessibility in school canteens, markets, and advertising of such foods on screens and media. Similar eating habits and preference of snacking items and beverages have also been reported in other studies performed on Turkish adolescents $(10,13,15)$.

As a result of the Dependent Sample T Test performed before and after education, it was observed that all three subgroups of ANLS had different and variable results. Firstly, FNL (basic reading and writing skills necessary to follow and understand simple nutrition information) increased at the end of education because students could read and comprehend texts easily. On the other hand, INL (advanced nutritional literacy involving cognitive and interpersonal communication skills necessary to manage nutritional issues in collaboration with professionals) and CNL (ability to critically analyze nutritional information, the ability to overcome barriers and act in order to raise awareness) decreased after the training. This could be explained by the fact that students may not have followed advanced part of the training within the short period and may have responded to the questionnaires without comprehending and influenced by peers. Another reason may be that the compact nutritional information presented in a short time was unable to create the expected impact, the presentation techniques may not have been very emphatic and finally the timing of the post-test coinciding with the Final exams may have resulted in students responding to the questionnaires in a careless and haphazard manner. Moreover, nutritional habits in individuals develop over time reflecting culture and family traditions and does not change easily. Nevertheless, repeated trainings and education creating awareness in the society is bound to bring positive changes in the long run.

In this study, Adolescent Food Habits (AFHC) scores were found to decrease at the end of nutrition training. The short compact training failed to have an impact on the food habits of the participants. Studies performed on food habits of adolescents indicate that the young age groups are inadequately nourished and have an unbalanced diet $(14,16,17)$. In a study evaluating Nutritional Habits Index (NHI) of adolescents, nearly all participants were found to be at risk in terms of nutritional habits and $64,5 \%$ were in the medium and $22,5 \%$ in the high-risk group (18).

In this study, in general females had a higher nutrition literacy level and better food habits scores as compared to males. The results were similar to the study performed by Matsumoto et al on 1165 Japanese adults between 18-24 years of age (19) and some other studies analysing the relationship between nutrition knowledge and genders $(20,21)$. The author also suggested that eating behaviors of individuals were affected by nutritional literacy (3). In the prevention of obesity-related chronic diseases, awareness of young adults about healthy nutrition will be of great importance. Adolescents are influenced by family, friends, peers, media, advertisements etc in food selection. Fast foods are preferred as they are cheap, easily accessible and savory due to high salt, sugar and fat content. Attention must be drawn towards food process owners who have added responsibility in the production and sale of reliable food. Apart from parents and family members, teachers must also supervise the nutrition habits of children right from the elementary school, raising awareness by organizing training for various age groups, stressing on the consequences of unhealthy nutrition. it is recommended to draw people's attention by creating public spots and often publishing them in news sources (22).

\section{CONCLUSION}

Although nutrition literacy issues have been addressed in several studies in Turkey, yet such a project as experimented in this study on a group of adolescents (investigating the effect of a training on nutritional awareness and food habits) has not been conducted in this region of the country. Contrary to the expectations, the study implemented here was not effective as per the results. As mentioned above there may have been many reasons not fully understood that may have led to these unexpected findings. Therefore, it is extremely important to consider these issues in the future studies and it is thought that the possible reasons leading to this result should be investigated in depth and a more comprehensive and longer education should be provided in schools to raise awareness of students and adolescents in the field of nutrition and health.

Conflict of Interest: None stated by the authors.

Funding: No funding was received for this study. 


\section{REFERENCES}

[1] Altay M, Cabar HD, Altay B. Adolesan döneminde beslenme ve okul sağlığı. Sinop Üniversitesi Sosyal Bilimler Dergisi 2018;2(1):173-180.

[2] Ronto R, Ball L, Pendergast D, Harris N. Adolescents' perspectives on food literacy and its impact on their dietary behaviours. Appetite 2016;107:549-557.

[3] Kalkan I. The impact of nutrition literacy on the food habits among young adults in Turkey. Nutr Res Prac 2019;13(4):352357.

[4] Bell MG, Zeiler M, Herrero R, Kuso S, Nitsch M, Etchemendy E, Baezae S, Olivere E, Adamcik T, Karwautzb A, Wagner G, Banos R, Botella C, Görlich D, Jacobii C, Waldherr K. Healthy teens school: Evaluating and disseminating transdiagnostic preventive interventions for eating disorders and obesity for adolescents in school settings. Internet Interventions 2019;16:65-75.

[5] [5] Arslan M, Aydemir I. Relationship between emotional appetite, eating attitudes, sleep quality and body mass index in healthcare workers: a multı-centre study. Psychiatr Clin Psychopharmacology 2019;29 (3):346-353.

[6] Bari NN. Nutrition Literacy Status Of Adolescent Students in Kampala District, Uganda", Master Thesis. Oslo and Akershus University College of Applied Sciences, Lillestrøm, Norway. 2012.

[7] Türkmen AS, Kalkan I. Filiz E. Adolesan Beslenme Okuryazarlığı Ölçeğinin Türkçe' ye uyarlanması: geçerlilik ve güvenilirlik çalışması. Uluslararası Hakemli Beslenme Araştırmaları Dergisi 2017;10:117-125.

[8] Johnson F, Wardle J, Griffith J. The adolescent food habits checklist: reliability and validity of a measure of healthy eating behaviour in adolescents. Eur J Clin Nutr 2002;56:644-649.

[9] Arikan I, Aksu AE, Metintas S, Kalyoncu C. The adaptation of the adolescent food habits checklist to Turkish young adults. TAF Rev Med Bull 2012;11:49-56.

[10] Aksoydan E, Çakır N. Adölesanların beslenme alışkanlıkları, fiziksel aktivite düzeyleri ve vücut kitle indekslerinin değerlendirilmesi. Gülhane Tıp Dergisi 2011;53:264-270.

[11] [11] WHO Global Health Observatory Data Repository [online database]. Geneva, World Health Organization, 2013 (http:// apps.who.int/gho/data/view.main, accessed 21 May 2013)
[12] Şanlıer N. Gençlerde biyokimyasal bulgular, antropometrik ölçümler, vücut bileşimi, beslenme ve fiziksel aktivite durumlarının değerlendirilmesi. GÜ, Gazi Eğitim Fakültesi Dergisi 2005;25(3):47-73

[13] Sağlam F, Yürükçü S. Ankara Üniversitesi Eğitim Bilimleri Fakültesi Yüksekokul öğrencilerinin besin tüketim durumu, beslenme alışkanlıkları ve beslenme bilgi düzeylerinin saptanması. Beslenme ve Diyet Dergisi 1996;25(2):16-23.

[14] [14] Kalkan i, Türkmen A, Filiz E. Dietary habits of Turkish adolescents in Konya, Turkey. Global Journal on Advances in Pure \& Applied Sciences 2015;7:190-196.

[15] Tözün M, Sözmen MK, Babaolu AB. Türkiye'nin batısında bir üniversite'nin sağlık ile ilişkili okullarında beslenme alışkanlıkları ve bunun obezite, fizik aktivite ve yaşam kalitesi ile ilişkisi. Türk Dünyası Uygulama ve Araş Merkezi Halk Sağlığı Derg 2017;2(1):1-16.

[16] Sevil J, Garcia Gonzalez L, Abos A.,Generelo E, Aibar A. Can high schools be an Effective Setting to Promote Healthy Lifestyles? Effects of a Multiple Behavior Change Interventionin Adolescents. J Adolescent Health 2019;64:478-486.

[17] Addressing nutritional disorders in adolescents. Position paper /J Adolescent Health 63, 2018;120-123.

[18] Altundağ S, Ceylan SS, Çetinkaya B, Turan T. Meslek lisesi öğrencilerinin obesite sıklığının ve beslenme alışkanlıklarının incelenmesi. TAF Prev Med Bull 2009;8(1):5-12.

[19] Matsumoto M, Ishige N, Sakamoto A, Saito A, Ikemoto S. Nutrition knowledge related to breakfast skipping among Japanese adults aged 18-64 years: a cross-sectional study. Pub Health Nutr 22(6), 1029-1036.

[20] Hendrie GA, Coveney J, Cox D. Exploring nutrition knowledge and the demographic variation in knowledge levels in an Australian community sample. Pub Health Nutr 2008; 11, 1365-1371.

[21] Parmenter K, Waller J, Wardle J. Demographic variation in nutrition knowledge in England. Health Educ Res 2000; 15, 163-174.

[22] Sinir G, İncedayı B, Çopur ÖU, Kaplan E, Bekaroğlu M. Uludağ Üniversitesi'nde eğitim gören öğrencilerin beslenme alışkanlıklarının araştırılması U. Ü. Ziraat Fakültesi Derg 2014; 28(2):37-47. 